IJMS 22 (1), 1-22 (2015)

\title{
THE RELATIONSHIP MARKETING AS A DETERMINANT OF CUSTOMER SATISFACTION IN ISLAMIC BANKING SERVICES MANAGEMENT
}

\author{
NUR SYAMILAH MD NOOR \\ Master in Islamic Finance and Banking \\ Universiti Utara Malaysia \\ HYDZULKIFLI HASHIM OMAR \\ Islamic Business School \\ Universiti Utara Malaysia
}

\begin{abstract}
The purpose of this study is to identify the dimensions that determine whether customer satisfaction in Islamic banking services has been conducted at the Institusi Pengajian Tinggi Awam (IPTA) in Perlis involving two institutions, namely Universiti Malaysia Perlis (UNIMAP) and Universiti Teknologi Mara (UITM) Perlis. The collection of the principal data was accomplished by using a survey paper to answer the study's research questions. It involved 224 customers using the Islamic banking services. This study was analysed using the Statistical Packages for Social Science (SPSS) by applying descriptive analysis and inferential analysis (Independent T-test, One Way Analysis of Variance (ANOVA) and Correlation Pearson). This study finds that there are some different relationships in terms of position at the university level of education in the demographic characteristics analysis towards customer satisfaction. Most of the dimensions related to customer satisfaction in the Islamic banking services are positively correlated with each other (commitment, product knowledge, competence, service encounter). This study proves that this research is useful to academicians by providing new empirical evidence of relationship marketing with customer satisfaction in the Islamic banking industry. The results of this study can encourage bank managers to learn how to improve commitment, product knowledge, competence and service encounter in Islamic banks' services to customers.
\end{abstract}


Keywords: Islamic banking services, customer satisfaction, relationship marketing, service quality, service encounter, commitment, product knowledge and competence.

\title{
Introduction
}

The development of Islamic banking in Malaysia has grown rapidly from the challenges of having a dual-banking system - a conventional banking system operating contiguous to the Islamic banking system. Thus, the products offered by the Islamic banking institutions have to compete with the long-established conventional banking system. However, the full-fledged Islamic banking system in Malaysia has been in existence for the past 30 years with the establishment of Bank Islam Malaysia Berhad (BIMB). Haron and Wan Azmi (2005) also argued that Islamic banks in Malaysia do not aggressively market their products. They suggested that Islamic banks should have a better understanding of the needs, preferences and behaviour of their target customers. Customers will use the Islamic banks when the services are good and meet their needs. Therefore, Islamic banks should be concerned with customer needs by establishing a good relationship between their employees and customers as stated by Allah SWT in the Quran:

\begin{abstract}
"...And cooperate in righteousness and piety, but do not cooperate in sin and aggression. And fear Allah; indeed, Allah is severe in penalty"
\end{abstract}

(Surah Al-Māidah 5: 2)

Furthermore, the Islamic banking service is a system of banking services consistent with the Principles of Islamic Law (Shariah). For emphasis the Islamic system in a bank must have a Shariah Advisory Board. The responsibility of the board is to ensure that the products and services offered by the bank are consistent with Shariah principles at all times. Customers that have any uncertainty about the integrity of the Shariah Advisory Board are advised to complain directly to the Central Bank of Malaysia (CBM) because all banks operating in Malaysia are under the patronage of CBM (Kamarulzaman \& Madun, 2013). Kamarulzan and Madun (2013) review a proof based on Lee and Detta (2007) that more reputable banks try to provide Islamic banking products to make the Islamic banking system no longer a theoretical idea but a practical one in the industry. That means the 
full-fledged Islamic banks provided services similar to commercial and investment banks. The management of the institution's better than conventional bank services.

In the banking sector, the market gradually introduced Islamic banking products but the acceptance of marketing was not encouraging (Kamarulzaman \& Madun, 2013). In order to support the development of Islamic banks attention should be given to measure the effectiveness of marketing and customer satisfaction. For example, how the product is promoted, as promotional activities support in crafting or altering consumers perceptions. A continuous review of marketing Islamic banking products is what is needed, as suggested by Kotler (2003).

\section{Problem Statement}

This study focused on customer satisfaction of the Islamic banking services. In order to evaluate customer satisfaction, the researcher investigated the factors of service quality and relationship marketing of the Islamic banking services particularly in Malaysia.

In service quality, there are 3 main areas for improving customer focus on customer satisfaction (Atkearney, 2012). The first factor that influences customer satisfaction is staff's ability. Usually in the banking service, the staff have always lacked understanding of the products they are selling. This is even more noticeable in Islamic banking, where customers may necessitate additional explanations of the shariah-compliant product structures. There is a need to improve responsiveness from customers if they do not receive a call-back within the promised time. The second factor is the lack of information. In this situation, customers do not receive important information about some products or services before purchase such as customers do not know about the extra charges after a sale. Consequently, the lack of information will affect brand loyalty. Then, information concerning Islamic banking is limited and not enough to convince the customers. For instance, the Islamic bank's website provides minimal information about a product that is offered; less than conventional banks. The third factor is touch points. A touch point is known as a reference for customers in a fast way. Customers often have limited call-centers or website service options and are repeatedly referred from one department to another. Few Islamic banks have a multichannel view of the customer (Bank Islam Malaysia Berhad, 2012). 
Based on the above statement, the researcher aimed to investigate some dimensions related to customer satisfaction of the Islamic banking services in order to improve the services in Islamic banks.

\title{
Literature Review
}

Customer satisfaction means the extent to which a customer's needs, wishes and expectations towards the products and services are fulfilled. During sales, customers are encouraged to repurchase and be loyal customers (Kocoglu \& Kirmacil, 2012). In other words, customer satisfaction is the valuation of the pre-purchasing expectations for the product, with the results reached after the act of purchasing. Customer satisfaction is a concept to determine how the products or services delivered meet or exceed a customer's expectation (Christopher, Payne, \& Ballantyne, 1991). Furthermore, customer satisfaction is important to maintain good relations between the seller and the buyer in business activities as stated in the Quran:

\begin{abstract}
"Believers, do not eat each property among yourselves for vanities, except in the case of trade with equally acceptable between you"
\end{abstract}

(Surah al-Nisā 4: 29)

Based on Kotler (2000), satisfaction refers to a person's feeling of pleasure or disappointment resulting from a product's performance in relation to his her expectation. Besides that, the key indicator within the firm and an element of business strategy particularly in a competitive market where a business competes for customers is customer satisfaction (Shamsudin, Hassan, \& Nor Azmi, 2010). Therefore, measuring customer satisfaction provides a key of how successful the firm's in producing products and services in the market. According to Kotler (2000) a highly satisfied customer can be identified as follows:

1. The customer continues his shopping for a long time.

2. They buy more as long as the firm produces new products and the existing products are improved.

3. They speak about the firm and its products with praise.

4. They keep does not care to another brands that are in competition with the products of the firm and does not emphasis on the price.

5. They will give the firm suggestions and ideas about products and services. 
Kotler (2003) was determined that customer satisfaction is an abstract concept and the actual expression of satisfaction. The variables which correlate with satisfaction behaviours determine the proof of customer satisfaction. In addition, the level of satisfaction can be different depending on how the customer compares the firm's products or services. Currently, a lot of research in customer satisfaction is being done. The common measures of customer satisfaction studies carry surveys whereby selected respondents are requested to evaluate the performance of the selected firm or organization.

Lovelock, Patterson, \& Walker (1998) list the features of customer satisfaction in their study as follows:

1. Satisfaction is related link to customer loyalty and relationship commitment.

2. Highly satisfied customers by word-of-mouth become walking and talking advertisements for an organization whose service has pleased them.

3. Highly satisfied customers may be more forgiving when they have been enjoying good delivery service many times in the past. It is believed that service failure is a deviation from the norm.

For the purpose of this study, the dimension of Relationship Marketing (RM) was used and it was proposed by Ndubisi and Chan (2005). Razali, Salleh and Abdullah (2013) is the main reference in developing the questionnaires. Caceres \& Paparoidamis (2007); Omar and Ali (2010) continued their previous research according to the dimensions of RM and studied the Islamic banking system in Malaysia. They used three dimensions which were commitment, product knowledge and competence. On the other hand, researchers added two other dimensions from Kishada and Wahab (2013) and Parasuraman and Zeithmal (1988) which were service encounter and responsiveness based on their functions in service quality.

According to Hadvaldar (2010), relationship marketing focuses on collaborative or partnership relationships between the customer and the firm. The aim of relationship marketing is to build mutually satisfying long-term relationships between key parties such as customers, suppliers, and distributors in order to gain and retain business. Relationship marketing builds strong economic, social and technical ties for developing a strong customer brand or loyalty. 
Furthermore, service, to a customer, is sometimes more important than the physical product because customer service supplements the sales of physical products and creates a total value for the customer.

To achieve success in the complex and competitive market of today, researchers have maintained and practitioners agree that customer satisfaction is the key of relationship marketing(Ndubisi \& Chan, 2005). Thus, a number of key areas that need to be considered if the customer is to be served satisfactorily have been prescribed. One of these key areas to leverage firm customer relationship is to gain confidential information about customers' needs and serve them satisfactorily. Therefore, relationship marketing attempts to get the firm close to the customers in order to enable it to accurately and adequately differentiate and satisfy their needs. According to Ndubisi (2004) a study on relationship marketing is necessary as different implications may be extracted that will assist marketing practitioners in designing effective customer management and customer satisfaction strategies. The outcome of this research holds significant benefits for marketing researchers and practitioners interested in the subject of customer relationship management and customer satisfaction.

Other than relationship marketing, service quality also has a strong relationship to customer satisfaction. Nowadays, service quality has become one of the important determinants in measuring the success of industries. According to Parasuraman, Zeithaml, and Berry (1985); stated on Avkiran, (1994); Mersha \& Adlakha, (1992); Marshal and Murdoch (2001), marketers agree that service quality has truly presented a significantinfluence on customers to distinguish competing organizations and contribute effectively to customer satisfaction. The researchers also made a comparison between customer expectations and perception in service performance, a bank trying to determine the expectations of the customers by their previous experience to improve their service quality and another bank trying to market their product to meet their customers' expectations.

The combination of relationship marketing and service quality towards customer satisfaction was supported by Bennett and Barkensjo (2005); Roberts, Varkie and Brodie (2003) in their research as the interaction of the Relationship Marketing in current practices show a positive reaction in satisfaction and over time also enhances perceptions of service quality leading the customer to positively feel more secure in the relationship of business. Based on the literature, the schematic diagram for the conceptual framework is as follows: 


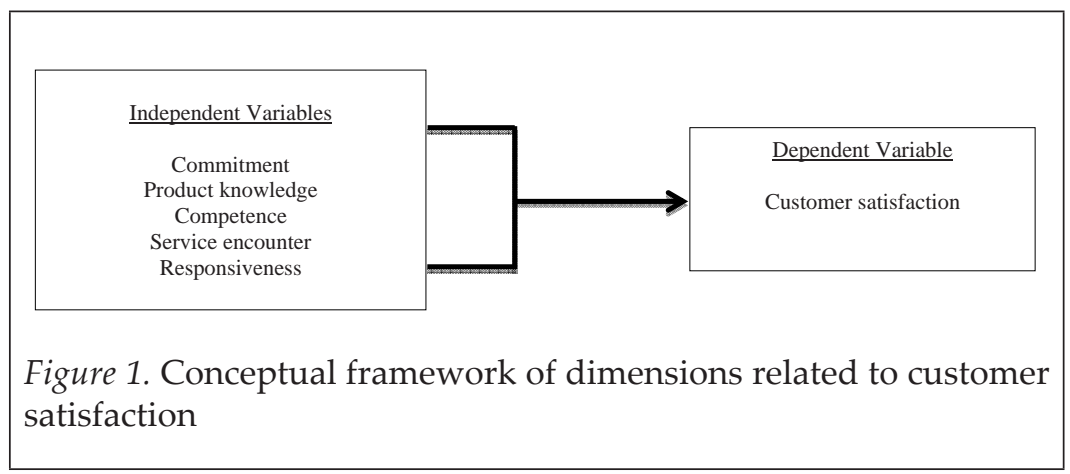

This study was undertaken with the dimension of relationship marketing and service quality as independent variables and customer satisfaction as the dependent variable. Factors of RM focus on the dimensions of commitment, product knowledge and competence. Other dimensions of service quality were service encounter and responsiveness. This study also examined the differences between selected demographic factors such as gender, position in the university, banks used, age, and level of education.

\section{Research Hypotheses}

These hypotheses are guides for the evaluation of the entire process of the research effort and they keep the research on the main line of the study. The following were the hypotheses for this research work:

H1 : Demographic factors (gender, position in university, bank used, age, and level of education) have a different relationship with customer satisfaction.

Differences between gender, position in university, types of bank used with customer satisfaction

H1a : There is a significant difference between gender and customer satisfaction.

$\mathrm{H1b}$ : There is significant difference between position in university and customer satisfaction.

H1c : There is significant difference between bank used and customer satisfaction. 
IJMS 22 (1), 1-22 (2015)

Differences between age and level of education with customer satisfaction

H1d : There is significant difference between age and customer satisfaction.

H1e : There is significant difference between levels of education and customer satisfaction.

H2 : There are relationships between commitment, product knowledge, competence, service encounter, responsiveness, and customer satisfaction.

Relationship between the dimensions and customer satisfaction

H2a : Commitment has an association with customer satisfaction.

$\mathrm{H} 2 \mathrm{~b}$ : Product knowledge has an association with customer satisfaction.

H2c Competence has an association with customer satisfaction.

$\mathrm{H} 2 \mathrm{~d}$ : Service encounter has an association with customer satisfaction.

H2e : Responsiveness has an association with customer satisfaction.

\section{Scope of Study}

The scope of this study only emphasizes the dimensions relating to customer satisfaction, particularly among customers (employees) of the Islamic banks in Institusi Pengajian Tinggi Awam (IPTA) in Perlis. The respondents were chosen from among the users of Bank Islam Malaysia Berhad (BIMB) and Bank Muamalat Malaysia Berhad (BMMB). This study investigates some of the factors related to relationship marketing and service quality on customer satisfaction. Therefore, the purpose of this study is to determine the differences between the factors influencing customer satisfaction and the demographic characteristics (gender, age, ethic, educational level, position, and bank usage frequency). Importantly, the relationship between customer satisfaction and the dimensions will be tested according to the current services of the Islamic banks. 


\section{Methodology}

The operational definition refers to the questions (items) that are used in a survey to measure the meaning of a construct (Hair, Babin, Money, \& Samouel, 2003). The constructs used in this study were customer satisfaction, commitment, product knowledge, competence, service encounter and responsiveness. With the exception of the demographic factors, all variables included in this study were measured using multiple items drawn from previous research. However, the items were modified to suit the sample and specific terms.

The scales have been validated and the high reliability reported for each item was modified for this study. After implementing the pilot study, the secondary data collected for the study needed to be analysed through factor analysis. Instruments were adopted from previous validated research and this analysis was implemented to fulfill the objective of this study. The researcher combined two different instruments in the independent variables. In that regard, factor analysis was performed to ensure the instruments were reliable for this study.

The items were phrased in the form of statements as part of the survey to investigate customer satisfaction of the Islamic banking services. Table 1 below shows the measurement of the variables which were involved in this study.

Table 1

Measurement of the Variables

\begin{tabular}{lccl}
\hline Measurement & \multicolumn{2}{c}{ Questionnaire } & Source \\
& $\begin{array}{c}\text { Number of } \\
\text { questions }\end{array}$ & Total & items \\
\hline Competence & $1-3$ & 3 items & Ndubisi and Chan, (2005) \\
Product knowledge & $4-8$ & 5 items & Razali et al. (2013) \\
Competence & $9-12$ & 4 items & Ndubisi and Chan, (2005) \\
Service encounter & $13-16$ & 4 items & Kishada and Wahab (2013) \\
Responsiveness & $17-20$ & 4 items & Parasuraman and Zeithmal, (1988) \\
Customer satisfaction & $21-25$ & 5 items & Ndubisi and Chan (2005) \\
\hline
\end{tabular}


In this research, population is defined as the total category of subjects which is the focus of attention in a particular research project. The population in this study was the staff of IPTA located in Perlis. Each individual was the unit of analysis for this study, which referred to UNIMAP and UITM in Perlis. Each individual's response was considered an independent data source. IPTA staff were chosen as the study sample for several reasons. Firstly, employing university staff for this study was appropriate because they were possible buyers with good purchasing power. Secondly, UNIMAP and UITM, staff have a huge potential of using the products and services of Islamic banks. In other words, they were an important target market for Islamic banks to promote their products in a particular market. This was because the salaries of the UNIMAP and UITM staf were paid through BMMB and BIMB accounts. Therefore, the respondents were experienced and used Islamic banking products and services because most of the respondents had accounts in Bank Islam Malaysia Berhad (BIMB) and Bank Muamalat Malaysia Berhad (BMMB). However, the respondents different in demographic composition such as educational level and position in the University.

This study chose cluster sampling in the probability sampling method to collect the data easily. The IPTA, Perlis staff were divided into selected clusters: departments, units, centers and schools. According to Sekaran (2003), costs of cluster sampling are less than those of other probability sampling designs such as simple or stratified random sampling or systematic sampling. Nerveless, cluster sampling exposes itself to greater biases and is the least generalizable of all the probability sampling designs because most naturally occurring clusters in the organizational context do not contain heterogeneous elements. In other words, cluster sampling technique is not very common in organizational research but could be used with marketing research activities.

Based on the information from the Registrar's department, the total number of UNIMAP staff was 1700 and UITM, Perlis was 833. After the total number of staff for each cluster had been identified, the samples in the clusters were be chosen randomly by the officer-incharge, so that all employees in the clusters would be included in the sample. The study was carried out using the survey approach. The population of the study consisted of 2533 persons of which UNIMAP staff numbered 1700 and UITM, Perlis staff were 833 . Therefore, the number of samples selected from the population was based on the sample size tables of Krejcie and Morgan (1970), which state that for a population size of 2600 the number of samples required was 
335 (Sekaran, 2003). However, the researcher personally distributed 350 sets of questionnaires to the respective respondents according to the list of clusters. The response rate for this research was $64 \%$; 224 questionnaires were collected in this study. The amount of data collected could be accepted because according to Roscoe (1975) cited in the book written by Sekaran (2003), any sample size greater than 30 and less than 500 is applicable to most studies.

\section{Analysis of Demographic Factors}

Descriptive statistics are used to explore, review and describe all the data collected when a study is undertaken (Coakes \& Steed, 2007). Descriptive statistics may be particularly useful in that general observations can be made from the data collected using demographic questions. The demographic factors in this research were gender, age, race, level of education, position and type of bank used.

\section{Gender of Respondents}

Table 1

Gender of Respondents

\begin{tabular}{lcc}
\hline Gender & Frequency & Percent $(\%)$ \\
\hline Male & 100 & 44.6 \\
Female & 124 & 55.4 \\
Total & 224 & 100.0 \\
\hline
\end{tabular}

The table shows the gender of the respondents. In terms of gender, the 224 respondents were evenly distributed between the two major gender categories. The sample contained $124(55.4 \%)$ females and the rest were males $100(44.6 \%)$.

\section{Race of Respondents}

Table 2

Race of Respondents

\begin{tabular}{lcc}
\hline Race & Frequency & Percent $(\%)$ \\
\hline Malay & 219 & 97.8 \\
Chinese & 3 & 1.3 \\
Siamese & 2 & 0.9 \\
Total & 224 & 100.0 \\
\hline
\end{tabular}


IJMS 22 (1), 1-22 (2015)

Table 2 shows that 219 (97.8\%) of the respondents were Malays, while $3(1.3 \%)$ were Chinese and 2 were Siamese $(0.9 \%)$. Most of respondent were Malays because during the period of observation, the majority of the staff in IPTA, Perlis were Malays. So this research excluded the Chinese and the Siamese.

\section{Age of Respondents}

Table 3

Age of Respondents

\begin{tabular}{lcc}
\hline Age & Frequency & Percent $(\%)$ \\
\hline 24 years and below & 34 & 15.2 \\
25-34 years & 115 & 51.3 \\
$35-44$ years & 51 & 22.8 \\
45 years and above & 24 & 10.7 \\
Total & 224 & 100.0 \\
\hline
\end{tabular}

The result of respondents' age is shown in the table above. The table shows 34 respondents $(15.2 \%)$ were 24 years and below, followed by 115 respondents (51.3\%) between 25 to 34 years $51(22.8 \%)$ between 35 44 years and $24(10.7 \%)$ were 45 years and above. Most of respondents were between 25 to 34 years old. This was because these respondents dealt more with the bank than the other age groups.

\section{Position in University}

Table 4

Position in University

\begin{tabular}{lcc}
\hline Position & Frequency & Percent $(\%)$ \\
\hline Academician & 61 & 27.2 \\
Administrative staff/ Support staff & 163 & 72.8 \\
Total & 224 & 100.0 \\
\hline
\end{tabular}

The table shows the position of respondents in the area of study. In IPTA usually there are two types of positions which are academicians and administrative staff/support staff. The sample contained 61 $(27.2 \%)$ academician and the rest $163(72.8 \%)$ were administrative staff/support staff. 


\section{Level of Education of Respondents}

Table 5

Level of Education of Respondents

\begin{tabular}{lcc}
\hline Level of Education & Frequency & Percent $(\%)$ \\
\hline SPM & 61 & 27.2 \\
STPM/ Certificate/ Diploma & 66 & 29.5 \\
Bachelor degree & 43 & 19.2 \\
Postgraduate degree & 54 & 24.1 \\
Total & 224 & 100.0 \\
\hline
\end{tabular}

The levels of education of the respondents are shown in Table 5. 61 (27.2\%) respondents hold SPM. Diploma/Certificate/STPM holders were $66(29.5 \%)$ of the total number of respondents. Bachelor degree holders, number of $43(19.2 \%)$. A total of $54(24.1 \%)$ were postgraduates.

\section{Banks Used by Respondents}

Table 6

Banks used by Respondents

\begin{tabular}{lcc}
\hline Bank & Frequency & Percent $(\%)$ \\
\hline BIMB & 113 & 50.4 \\
BMMB & 111 & 49.6 \\
Total & 224 & 100.0 \\
\hline
\end{tabular}

Table 6 shows the banks used by the respondents. The Islamic banks that were involved in this study were Bank Islam Malaysia Berhad (BIMB) and Bank Mualamat Malaysia Berhad (BMMB). 113 (50.4\%) chose BIMB and the 111 (49.6\%) chose BMMB.

\section{Differences between Gender, Position in University, type of Bank Used and Customer Satisfaction}

The independent Sample T-Test analysis was conducted to test the null hypotheses in terms of gender, position in the University and bank used as follows. 
IJMS 22 (1), 1-22 (2015)

Table 7

Differences between Gender, Position in University, Bank Used and Customer Satisfaction

\begin{tabular}{llcccc}
\hline $\begin{array}{c}\text { Customer } \\
\text { Satisfaction }\end{array}$ & Category & Mean & $\begin{array}{c}\text { Std. } \\
\text { Deviation }\end{array}$ & T & Sig. \\
\hline Gender & Female & 3.74 & 0.71 & 0.14 & 0.89 \\
& Male & 3.73 & 0.58 & & \\
Position in & Academician & 3.90 & 0.62 & 2.39 & $0.02^{*}$ \\
university & Administrative staff/ & 3.67 & 0.63 & & \\
& support staff & & & & \\
Bank used & BIMB & 3.70 & 0.67 & -0.70 & 0.49 \\
& BMMB & 3.76 & 0.60 & & \\
\hline
\end{tabular}

Table 7 indicates the mean and standard deviation between the two groups (gender, position in University and bank used) and customer satisfaction.

\section{Gender and Customer Satisfaction}

H0a: There is no significant difference between gender and customer satisfaction.

H1a: There is a significant difference between gender and customer satisfaction.

The difference between male and female for customer satisfaction is relatively small. The difference in the mean is 3.74 and 3.73 respectively while $t$ value is 0.14 . The standard deviations of 0.71 and 0.58 for male and female for customer satisfaction were not significant $(p=0.89)$. Since, the significant level $(\mathrm{p}=0.89)$ is greater than the acceptable level of 0.05 , this analysis failed to reject the null hypothesis. Hence, there is no significant difference between males and females for customer satisfaction.

\section{Position in University and Customer Satisfaction}

H0b: There is no significant difference between position in University and customer satisfaction.

H1b: There is significant difference between position in University and customer satisfaction. 
As shown, the difference in position in University and customer satisfaction have means of 3.90 and 3.67 respectively while $t$ value is 2.39. The standard deviations of 0.62 and 0.63 for Academician and Administrative staff/support staff were significant $(p=0.02)$ are less than the acceptable level of 0.05 . Therefore this analysis was rejects the null hypothesis and accepts H1. Hence, there is a significant difference between academicians and administrative staff/ support staff for customer satisfaction.

\section{Bank used and Customer Satisfaction}

H0c: There is no significant difference between type of bank used and customer satisfaction.

H1c : There is significant difference between type of bank used and customer satisfaction.

The result of t-test for 'banks used' shows a mean of 3.70 and 3.76 while $t$ value is 0.70 . The standard deviations of is 0.67 and 0.60 for $\mathrm{BIMB}$ and $\mathrm{BMMB}$ respectively for customer satisfaction were not significant $(p=0.49)$. This is greater than the acceptable level of 0.05 . Therefore this analysis failed to reject the null hypothesis. Hence, it is concluded that there is no significant difference between banks used and customer satisfaction.

\section{Differences between Age and Level of Education with Customer Satisfaction}

Table 8

Differences between Age and Customer Satisfaction

\begin{tabular}{lcccc}
\hline Age & Mean & $\begin{array}{c}\text { Std. } \\
\text { Deviation }\end{array}$ & F & Significant \\
\hline 24 years and below & 3.76 & 0.77 & 0.59 & 0.62 \\
25-34 years & 3.70 & 0.59 & & \\
35-44 years & 3.70 & 0.63 & & \\
45 years and above & 3.88 & 0.63 & & \\
Total & 3.73 & 0.64 & & \\
\hline
\end{tabular}

From One-way ANOVA technique, the researcher will be able to tell whether there are any significant differences between the mean 
IJMS 22 (1), 1-22 (2015)

scores for customer satisfaction. A one- way ANOVA between group analysis of variance was conducted to explore the impact of age and level of education on the customer satisfaction by responden.

\section{Age and Customer Satisfaction}

H0d : There is no significant difference between age and customer satisfaction.

H1d: There is significant difference between age and customer satisfaction

Based on Table 8, the F-probability value is 0.59 and the significant value of customer satisfaction is 0.62 . This shows there are no significant differences in the means of age and customer satisfaction. Since the significance value is less than 0.05 ( $p \quad 0.05$ ), the null hypothesis is not rejected. Therefore, the age of the respondent does not give an impact on the dependent variable in this research. This might be because most of the staff have been treated equally as customers of the Islamic banks.

\section{Level of Education and Customer Satisfaction}

H0e: There is no significant difference between level of education and customer satisfaction.

H1e: There is significant difference between level of education and customer satisfaction.

Table 9

Differences in level of Education and Customer Satisfaction

\begin{tabular}{lcccc}
\hline Level of Education & Mean & Std. Deviation & F & Significant \\
\hline SPM & 3.75 & 0.58 & 3.12 & 0.03 \\
STPM/Certificate/Diploma & 3.62 & 0.61 & & \\
Bachelor degree & 3.62 & 0.72 & & \\
Postgraduate degree & 3.94 & 0.63 & & \\
Total & 3.73 & 0.64 & & \\
\hline
\end{tabular}

Table 9 points out that the F-probability value is 3.12 and the significant value of customer satisfaction is 0.03 . There is a significant difference between level of education and customer satisfaction. Since the significance value is less than 0.05 ( $\mathrm{p}$ 0.05), the null hypothesis 
is rejected. Therefore, this study concludes that there is a significant difference between level of education and customer satisfaction. Besides that, the respondents' levels of education had different opinions of customer satisfaction related to the services provided.

In order to determine the difference in the levels of education, the LSD table was observed. It was found that at least two groups had a significant difference between those with STPM/Certificate/Diploma and those with postgraduate degree (mean difference $=-0.32$, sig. $=0.01$ ) and Bachelor degree and postgraduate degree (mean difference $=-0.32$, sig. $=0.02$ ). The mean difference is significant at the 0.05 level. The LSD test is shown in Table 10 below.

Table 10

Post Hoc ANOVA LSD Analysis Level of Education

\begin{tabular}{lcccc}
\hline Level of education & SPM & $\begin{array}{c}\text { STPM/ } \\
\text { Certificate/ } \\
\text { Diploma }\end{array}$ & $\begin{array}{c}\text { Bachelor } \\
\text { degree }\end{array}$ & $\begin{array}{c}\text { Postgraduate } \\
\text { degree }\end{array}$ \\
\hline SPM & - & 0.24 & 0.32 & 0.11 \\
STPM/Certificate/Diploma & 0.24 & - & 0.95 & 0.01 \\
Bachelor degree & 0.32 & 0.95 & - & 0.02 \\
Postgraduate degree & 0.11 & 0.01 & 0.02 & - \\
\hline
\end{tabular}

Note. Figure in cells is significant value.

\section{Relationship between the Dimensions and Customer Satisfaction}

To test the second hypothesis, the researcher used the Pearson correlation. The significant level was at 0.01 . Table 11 provides a summary of the results of the correlation analysis. The computation of the Pearson correlation coefficients was performed to obtain an understanding of the relationship between all the variables in the study. The values of the correlation coefficients (r) given in table 11 indicate the strength of the relationship between the variables. This second hypothesis measured the strength of the relationship between dimensions and customer satisfaction as follows:

H2: There are relationships between commitment, product knowledge, competence, service encounter, responsiveness and customer satisfaction. 
IJMS 22 (1), 1-22 (2015)

H2a : Commitment has an association with customer satisfaction.

$\mathrm{H} 2 \mathrm{~b}$ : Product knowledge has an association with customer satisfaction.

$\mathrm{H} 2 \mathrm{c}$ : Competence has an association with customer satisfaction.

$\mathrm{H} 2 \mathrm{~d}$ : Service encounter has an association with customer satisfaction.

H2e : Responsiveness has an association with customer satisfaction.

\section{Table 11}

Correlations between Relationship of Dimensions and Customer Satisfaction

\begin{tabular}{lcc}
\hline Variables & $\begin{array}{c}\text { Customer satisfaction } \\
\text { Correlation coefficient (r) }\end{array}$ & Significant \\
\hline Commitment & $0.51^{* *}$ & 0.00 \\
Product knowledge & $0.47^{* *}$ & 0.00 \\
Competence & $0.51^{* *}$ & 0.00 \\
Service encounter & $0.62^{* *}$ & 0.00 \\
Responsiveness & 0.03 & 0.71 \\
\hline
\end{tabular}

${ }^{* *}$ Correlation is significant at ${ }^{* *} 0.01$ level (2-tailed).

Table 11 shows the correlation matrix between dimensions and customer satisfaction. There is a significant positive correlation between commitment and customer satisfaction with a significant value of 0.00 . Hence we reject the null hypothesis with a moderate relationship $(r=0.51)$. Meanwhile, there is a significant positive correlation between product knowledge and customer satisfaction with a significant value of 0.00 . Hence we reject the null hypothesis with a moderate relationship $(\mathrm{r}=0.47)$. There is also a significant positive correlation between competence and customer satisfaction with a significant value of 0.00 . Hence we reject the null hypothesis with a moderate relationship $(\mathrm{r}=0.51)$. In addition, there is a significant positive correlation between service encounter and customer satisfaction with a significant value of 0.00 . Hence we reject the null hypothesis with a moderate relationship $(r=0.62)$.

However, there is no significant positive correlation between responsiveness and customer satisfaction with a significant value of 0.71 . Hence we do not reject the null hypothesis. 
IJMS 22 (1), 1-22 (2015)

\section{Discussion}

The result of this study shows that there is no significant difference between gender, age, and bank used with customer satisfaction, whereas there is a significant difference between position in university and level of education with customer satisfaction. These findings answer the first research questions in terms of the differences between customer satisfaction and selected demographic factors (gender, age, position in university, banks used and level of education). Moreover, the result also indicates that 4 variables are significant and positively correlated with the customer satisfaction at the confident level of $99 \%$. This means that commitment, product knowledge, competence, and services encounter have good relationships with the dependent variable. Nevertheless, the one dimension that is not significant with the dependent variable is responsiveness.

In terms of correlation "service encounter" is positively and highly correlated than the other dimensions by moderate relationship (correlation coefficient) with customer satisfaction. It means that customers have positive insights of the service encounter. It happens when they are satisfied with the service provided by the Islamic banks especially service encounters. Therefore, service encounter is able to enhance customers' to dealing with the bank. According to Majid and Abed (2011), service encounter has become one of the important factors in measuring the success of industries. Thus, marketers stated that service quality had a significant influence on customers of competing organizations and contributed effectively to customer satisfaction. Nevertheless Kishada and Wahab (2013) found that service encounter did not influence customer loyalty at all.

"Commitment" is another dimension that is taken into consideration to assure customer satisfaction of Islamic banking services. Commitment is found to be positively and moderately related to customer satisfaction of Islamic banking services. This shows that the respondents whenever they deal with the bank, they will evaluate the commitment of the banks' employees towards the services provided. Commitment is needed when employees have a responsibility towards their jobs. Then, they will perform their jobs without making mistakes and will fully concentrate on treating the customers well. Therefore, the customer will remain loyal to the bank upon receiving great services (Musa, 2009). The dimension of commitment is an important factor in building customer trustworthiness; consisting, in this study, of accommodating customers' needs, tailoring products 
to requirements, and being generally flexible in their customer relationships. Banks should recognize the potency of service commitment in keeping loyal customers, and act accordingly. They must show genuine commitment to customer relations, not only lip service (Ndubisi, 2007).

The results of this research also indicate that "product knowledge" is positively correlated to customer satisfaction of Islamic banking services. This shows that customers are also looking at the advantages of the product while choosing the services provided. The customer will be satisfied with the product that is provided when they get better product knowledge from the banker including their knowledge of the benefits, latest products or information, and also knowledge about the difference between Islamic bank and conventional bank (Razali et al., 2013).

"Competence" is also found to have a positive and a moderate relationship with customer satisfaction. This shows that customers of the Islamic bank need competent services. Competence is important for service providers to build long-term relationship with their customers. Every customer likes to be treated with competent service which includes knowledge about banking services, knowledge about the market trends providing advice on how customers should invest their money, helping to plan investments, and providing effective sales promotions (Ndubisi \& Chan, 2005).

\section{Conclusion}

As expected, based on the findings, it appears that the dimensions related to customer satisfaction act as effective components in predicting customer satisfaction among the staff of IPTA, Perlis. This study has verified that 4 variables (service encounter, commitment, product knowledge and competence) had positive correlations with customer satisfaction. Therefore, Islamic banks, using the Islamic banking system in Malaysia, should consider those four significant variables as important dimensions in decision-making on service activities and also improve their services in future.

\section{References}

Atkearney. (2012, May). The future of Islamic banking. Retrieved from Atkearney http://www.atkearney.com.au 
Avkiran, N. K. (1994). Developing an instrument to measure customer service quality in branch banking. International Journal of Bank Marketing, 12(6), 10-18.

Bank Islam Malaysia Berhad. (2012, May 8). Bank Islam launches its first seven-day banking service. Retrieved from http://www. bankislam.com.my

Bennett, R., \& Barkensjo, A. (2005). Relationship quality, relationship marketing, and client perceptions of the levels of service quality of charitable organisations. International Journal of Service Industry Management, 16(1), 81-106.

Caceres, R., \& Paparoidamis, N. (2007). Service quality, relationship satisfaction, trust, commitment and business-to-business loyalty. European Journal of Marketing, 837-867.

Christopher, M., Payne, A., \& Ballantyne, D. (1991). Relationship marketing: Bringing quality, customer service and marketing together. London: Buterworth-Heinemann.

Coakes, S. J., \& Steed, L. (2007). SPSS: Analysis without anguish using SPSS version 14.0 for Windows. Australia: John Wiley \& Sons.

Hair, J., Babin, B., Money, A., \& Samouel, P. (2003). Essentials of business research methods. United States of America: Leyh Publishing.

Haron, S., \& Wan Azmi, W. (2005). Marketing strategy of Islamic banks: A lesson from Malaysia. International Seminar on Enhancing Competitive Advantage on Islamic Financial Institutions, Jakarta.

Havaldar, K. K. (2010). Business Marketing, text and cases. New Delhi: Tata McGraw-Hill Education.

Jabatan Perdana Menteri. (1987). Tafsir Pimpinan al-Rahman. Kuala Lumpur: Bahagian Hal Ehwal Islam.

Kamarulzaman, Y., \& Madun, A. (2013). Marketing Islamic banking products. Business Strategy Series.

Kishada, Z. M., \& Wahab, N. A. (2013). Factors affecting customer loyalty in Islamic banking: Evidence from Malaysian Banks. International Journal of Business and Social Science, 4(7), 264-273.

Kocoglu, D., \& KirmaciI, S. (2012). Customer relationship and customer loyalty: A survey in the sector of banking. International Journal of Business and Social Science, 3(3), 282-291.

Kotler, P. (2003). Marketing insight from A to Z 80 every manager needs to know. New York: John Wiley and Sons.

Kotler, P. (2000). Marketing management. New Jersey: Prentice Hall.

Krejcie, R. V., \& Morgan, D. W. (1970). Determining sample size for research activities. Educational and Psychological Measurement, 30, 607-610.

Lee, M., \& Detta, I. (2007). Islamic banking and finance law. Kuala Lumpur: Person Malaysia. 
Lovelock, C., Patterson, P., \& Walker, R. (1998). Services marketing. Sydney: Prentice- Hall.

Majid, N., \& Abed, A. (2011). Measuring the perceive service quality in the Islamic banking system in Malaysia. International Journal of Business and Social Science, 2(13), 122-133.

Musa, N. A. (2009). The impact of relationship marketing on customer loyalty in the banking sector. Sintok: Universiti Utara Malaysia.

Marshall, G., \& Murdoch, L. (2001). Service quality in consulting marketing engineers. Oxford: Oxford Brookes University.

Mersha, T., \& Adlakha, V. (1992). Attributes of SQ: The consumers' perspective. International Journal of Service Industry Management, $3(3), 55-70$.

Ndubisi, N. (2004). Understanding the salience of culture dimension on relationship marketing, its underpinnings and aftermaths. Cross Culture Management, 70-89.

Ndubisi, N., \& Chan, K. W. (2005). Factorial and discriminant analyses of the underpinnings of relationship marketing and customer satisfaction. International Journal of Marketing, 542-557.

Ndubisi, N. (2007). Relationship marketing and customer loyalty. Marketing Intelligence and Planning, 98-100.

Omar, M. W., \& Ali, M. N. (2010). Brand loyalty and relational marketing in Islamic banking system. Canadian Social Science, $6(1), 25-32$.

Parasuraman, A., \& Zeithmal, L. B. (1988). SERVQUAL: Multiple item scale for measuring customer perception of service quality. Journal of Retailing, 64(1), 12-37.

Parasuraman, A., Zeithaml, V. A., \& Berry, L. L. (1985). A conceptual model of service quality and its implications for future research. Journal of Marketing, 49, 41-50.

Razali, S. S., Salleh, M. C., \& Abdullah, N. I. (2013). Customer perception towards relationship marketing practices in takaful industry. Bandung: Indonesia.

Roberts, K., Varkie, S., \& Brodie, R. (2003). Measuring the quality of relationships in consumer services: An empirical study. European Journal of Marketing, 37(1), 169-196.

Sekaran, U. (2003). Research methods for business: A skill building approach. United States of America: John Wiley \& Sons.

Shamsudin, A. S., Mohd Kassim, A. W., Hassan, M. G., \& Nor Azmi, J. (2010). Preliminary insights on the effect of Islamic work ethic on relationship marketing and customer satisfaction. The Journal of Human Resource and Adult Learning, 6(1), 106-114. 